\title{
Pharmaceutical and Macromolecular Technologies in the Spirit of Industry 4.0
}

\author{
György Marosi1 ${ }^{1 *}$, Edit Hirsch11, Katalin Bocz¹, Andrea Toldy², Beáta Szolnoki', Brigitta Bodzay',

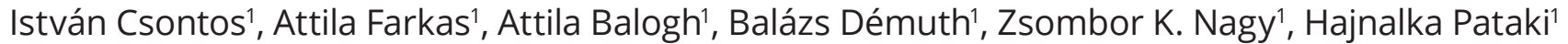

\footnotetext{
1 FirePharma group, FIEK-PharmaTech Laboratory, FlowBiotech Center, Department of Organic Chemistry and Technology, Budapest University of Technology and Economics, H-1111 Budapest, Műegyetem rkp. 3., Hungary

2 Department of Polymer Engineering, Faculty of Mechanical Engineering, Budapest University of Technology and Economics, H-1111 Budapest, Müegyetem rkp. 3., Hungary

*Corresponding author, e-mail: gmarosi@mail.bme.hu
}

Received: 16 July 2018, Accepted: 05 October 2018, Published online: 09 November 2018

\begin{abstract}
Well designed (multilayer, adaptive, reactive) interphases, being a key element of multicomponent structures, could be tailored to different requirements through controlled technologies. This is the link connecting various green, safe, healthy materials and innovative pharmaceuticals. Upgraded recycling could be performed by interfacial consolidation of self-reinforced composites, the flame retardancy of which is feasible with surprisingly low amount of flame retardant. Examples are shown how the reinforced and foamed forms of thermosetting and thermoplastic biopolymers can play a significant role (after flame retardant modification) in the development of airplanes and electric cars. Biopolymer nanofibres, such as polycaprolactone and polyhydroxybutyrate, could be formed with increased productivity for various medical uses. Raman-based control of the units of integrated continuous technologies has been elaborated including controlled formation of crystals with polymer interlayer for direct tableting.
\end{abstract}

\section{Keywords}

interface modification, recycling, biocomposites, pharmaceutical crystallization, Raman control

\section{Introduction}

Roots of the current research work to be described in this paper originate from activities on multicomponent polymer systems and composites, (fire) safety, recycling, oriented fibres, and formulation of pharmaceutical systems, as well as solid-state analysis and process control methods developed in the recent decades. The accumulated knowledge has been integrated by now to a coherent mind-set within the FirePharma group in a synergistic way. This proved to be a good basis for serving new technologies consisting of integrated interactive flow-type units. After highlighting some parts of this basis a short overview of the outcome is shown in this paper through selected examples.

Polymerization of lactames and acrylates, investigated by Bertalan and Anna [1, 2], reinforced the macromolecular chemistry knowledge in the first macromolecule school of Hungary founded by Zoltan Csürös.

More important stage of development was a basic (internationally patented) finding of multicomponent polymer systems utilized industrially by the largest Hungarian polymer producer company. The essence of this finding was a multilayer interphase that accomplished a smooth (mechanical and chemical) transition between different phases of composites (converting the well-known Buzaghprinciple to solid phase) [3]. Dielectric spectroscopy identified the Maxwell-Wagner-Sillars (MWS) interfacial polarization occurring in such composites [4]. Synthesis of reactive surfactants and the first proposal for their introduction into interphases of reinforced polymer systems further improved the stiffness-toughness balance of composites [5].

Reliable and reproducible synthesis of these additives required the development of a computer-controlled batch reactor system applying sequential controller program. It was used not only for preparing interfacial additives but also azo-pigments and polymer nanocomposites [6-9]. Completing the controlled reactor with a fibre-optic Raman probe and converting the complex Raman spectra to control signal, the first Raman-controlled processes could be developed and published $[10,11]$. 
Adaptive interfaces, that can be stimulated thermally, were also developed and applied around nanoparticles serving the fire safety of polymeric and composite structures. The developed non-halogenated flame retardancy principle utilized P-N-B-Si synergism and introduced also $\mathrm{CNT}$ and/or clay nanoparticles into the polymer matrices [12-15]. The internationally patented, finding could be utilized by a large German additive producing company [16]. Mathematical model of the mechanism of action described the performance of the fire retarded polymer system quite well supporting the scaled-up application [17].

Another patent referred to the recycling of crosslinked PE with thermally reversible urethane crosslink points [18]. Recycling proved to be especially advantageous and economic, when combined with flame retardancy. For this purpose PUR-waste, as active component of FR additive system, was introduced in polyolefin waste, furthermore, residue of glycolised PUR waste was found to have FR activity too [19-21].

Modified interphase initiated enhanced orientation and crystallinity in multicomponent fibres governed by local stress release mechanism. This phenomenon could be utilized both in technical and flame retarded polypropylene fibres [22, 23]. Nanofibres, prepared by electrospinning, became important in nanofiltration technology [24].

Pharmaceutical utilization of the knowledge, acquired through working with processing technologies of polymer fibres and nanocomposites, led the authors to apply Raman analysis, twin screw extrusion and nanofibre formation for drug delivery systems as well as to develop humidity-resistant nanostructured tablet coating [25-28].

These pioneering activities allowed learning important elements of green technology including the use of renewable materials with well-designed interphases, energy saving light-weight structures, green chemistry with organo- and biocatalysis, advanced monitoring, control and optimization and eco efficient flow technology with integrated, interactive units. Recent advancement in these fields, performed in FirePharma laboratories, is introduced through selected examples in the next sections.

\section{Experimental}

\subsection{Materials}

Drugs: carvedilol (Sigma-Aldrich, Hungary) with purity: $\geq 98 \%$, melting point: $117{ }^{\circ} \mathrm{C}$, spironolactone (Gedeon Richter Plc., Hungary) melting point: $205-220{ }^{\circ} \mathrm{C}$, water solubility at $25{ }^{\circ} \mathrm{C} 28 \mathrm{mg} / \mathrm{l}$, tolperisone hydrochloride (Sigma-Aldrich, Hungary) purity: $\geq 98 \%$ (HPLC) melting point: $171-174{ }^{\circ} \mathrm{C}$. In self-reinforced composites highly oriented isotactic polypropylene (iPP) homopolymer multifilament (Stradom S.A., Poland) was used as reinforcement and propylene-ethylene copolymer (rPP) based thermoplastic elastomer (Versify 4200, Dow Chemical Company, USA) was selected as matrix material. Biopolymers, were purchased from the producers: polylactic acid (PLA) of Ingeo ${ }^{\mathrm{TM}}$ Biopolymer 3052D type (NatureWorks LLC USA), polycaprolactone (PCL, Perstorp, $\mathrm{Capa}^{\mathrm{TM}}$ 6800, $\left.\mathrm{Mw}=80,000\right)$, polyhydroxybutyrate $(\mathrm{PHB}, \mathrm{Mw}=973,000)$ was obtained from the producer (Biomer, Germany). Intumescent flame retardant was Exolit AP462, (Clariant GmbH, Frankfurt am Main, Germany), a melamine formaldehyde resin micro-encapsulated ammonium polyphosphate (APP) based additive. Fibrous additives were multi-walled carbon nanotube (CNT) Baytubes C 150 HP (Bayer, Germany), and Ultrafine cellulose fibre (Arbocel UFC100 J. Rettenmaier \& Sohne $\mathrm{GmbH}$, Rosenberg, Germany) with average fibre length of $8 \mu \mathrm{m}$.

\subsection{Methods}

Raman image analyses were performed using a Horiba Jobin-Yvon LabRAM system coupled with an external $785 \mathrm{~nm}$ diode laser source and an Olympus BX-40 optical microscope. Small area maps were collected with $50 \times$ objective (laser spot size: $\sim 2.0 \mu \mathrm{m}$ ) and $6 \mu \mathrm{m}$ and $12 \mu \mathrm{m}$ step size in the $\mathrm{X}$ (perpendicular to the fibre orientation) and in the $\mathrm{Y}$ direction (parallel to the fibre orientation), respectively. In each experiment the acquisition time of a single spectrum was $30 \mathrm{~s}$ and 3 such spectra were averaged at each pixel. The analysed area was $36 \times 12$ pixels, i.e. 210 $\times 132 \mu \mathrm{m}^{2}$. Kaiser RamanRxn2 ${ }^{\circledR}$ Hybrid in situ analyser (Kaiser Optical Systems, USA) with a $400 \mathrm{~mW}, 785 \mathrm{~nm}$ diode laser (Invictus) and PhAT (Pharmaceutical Area Testing) probe was used for process-Raman measurements. Spectra were acquired with $15 \mathrm{~s}$ illumination time in the spectral range of $200-1890 \mathrm{~cm}^{-1}$ with a resolution of $4 \mathrm{~cm}^{-1}$.

Laser Pyrolysis-Fourier Transformed Infrared Spectroscopy (LP-FTIR) method is a coupled system consisting of a carbon-dioxide laser (10.6 $\mu \mathrm{m}$, SYNRAD 48-1), applicable for laser induced pyrolysis, connected with a special gas cell of FTIR spectrometer (Bruker Tensor 37 type, resolution: $4 \mathrm{~cm}^{-1}$, detector: DTGS). In situ FTIR allows their identification and quantification of components with 3D software of OPUS 5.5 without loss of any component.

Mass loss type cone calorimeter (made by FTT Inc) measurements were performed according to the ISO 13927 
standard method. Specimens $(100 \mathrm{~mm} \times 100 \mathrm{~mm})$ were exposed to a constant heat flux of $25 \mathrm{~kW} / \mathrm{m}^{2}$ and ignited.

Scanning electron microscopic (SEM) images were taken with a JEOL JSM-5500 LV type apparatus (JEOL Ltd., Akishima, Tokyo, Japan) applying accelerating voltages of 10-15 keV. All the samples were coated with goldpalladium alloy before examination.

\section{Results and discussion}

\subsection{Technologies of green, safe and healthy materials}

Composites, consisting of various polymers and inorganic constituents, represent the most serious problem when the practical implementation of recycling is in place. The inorganic reinforcements confuse the density-based sorting, cause abrasion of the milling units, support fire spreading (like the candlewick) and limit the applicability of recirculates. Our answer to this challenge is the development of fully recyclable self-reinforced FR-composites, in which both the matrix and reinforcing fibres are made of the same polymer family (e.g. polypropylene) and consolidated through their interfacial layers. This approach led us to an unexpected new advancement in fire-safety. An unknown mechanism of fire control has been recognized, which is governed by shrinkage of reinforcing fibres and thus contribute to extinguishing of fire. This way the amount of (harmless) FR additive, needed to achieve self-extinguishing level, could be reduced to one third of the original value [29, 30]. Such composites are easily processable by simple thermoforming methods if the level of heat-induced relaxation of the reinforcing fibres can be controlled. In order to facilitate this precise processing of self-reinforced composites, novel Raman monitoring and control methods have been proposed by the authors [31]. Scheme of the principle and Raman images visualizing the relaxation is shown in Fig. 1.
Recycling can utilize the in-line spectroscopic control in several ways. Sorting, based on infrared identification of each waste item, is well known, however, it cannot be applied for black pieces. A new laser pyrolysis-assisted (LP-FTIR) method, developed by the authors [32], solved this problem allowing identification of black wastes through their volatile pyrolysis products. Additionally, LP-Raman combination allows in-line control of intumescent flame retardant content (through its charring efficiency) along the production of FR composites. These approaches are shown in Fig. 2 a and b. Upgraded innovative recycled products could be developed by combining polyolefin fraction of selected wastes with flame retardant additives [33].

Flame retarded biopolymers represent another category of green and safe materials. Biocomposites suitable for airspace or other high-tech applications are, however, not available on the market. Therefore new sugar-based bioepoxy types have been synthesized recently that proved to meet the severe requirements of an airplane construction (e.g. glass transition temperature above $160^{\circ} \mathrm{C}$ ) [34]. Carbon fibre reinforced composites and natural fibre reinforced fullbio composites could be developed in fire-safe form and the latter one processed to airplane furniture as shown in Fig. 3.

Unique epoxy-composite was required for the protection of an airplane, made of polymer composite, against lighting attack. The requirement, beyond the mechanical chemical and thermal resistance, was electrical conductivity as well. For this purpose conductive nonwoven reinforcement made of carbon nanofibre, containing carbon nanotubes (shown in Fig. 4), were developed and prepared in a special continuous oven [35].

Thermoplastic all-bio composites in flame retarded form have been prepared at the first time by the authors $[36,37]$. Such safe and light-weight composites are especially advantageous for producing electrical cars, in which

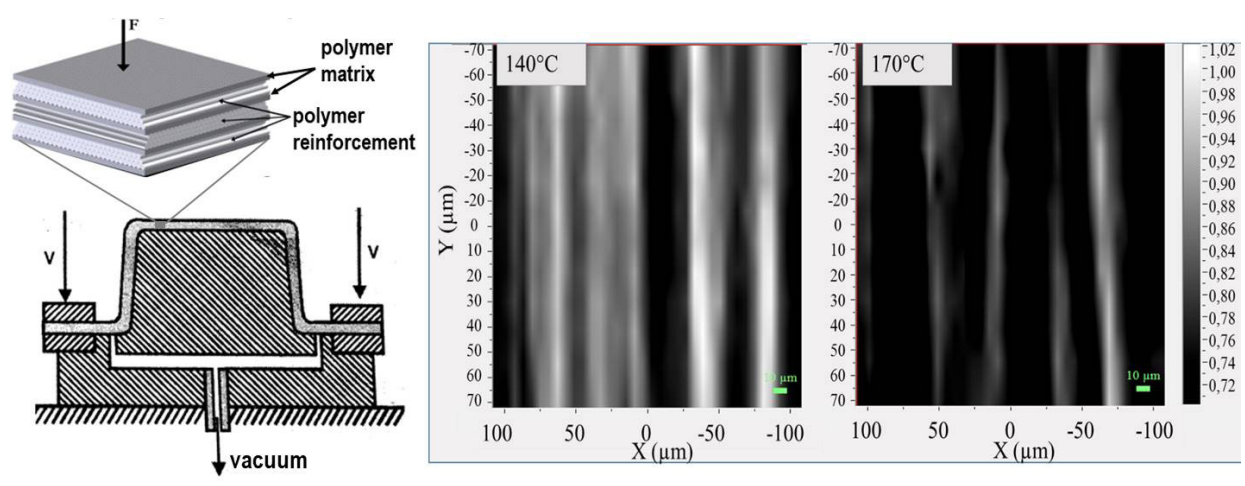

Fig. 1 Thermoforming of self-reinforced polypropylene composite and demonstration of the heat-induced relaxation of reinforcing fibres by Raman mapping (bright bands represent the oriented fibres, while the dark bands the relaxed ones) 


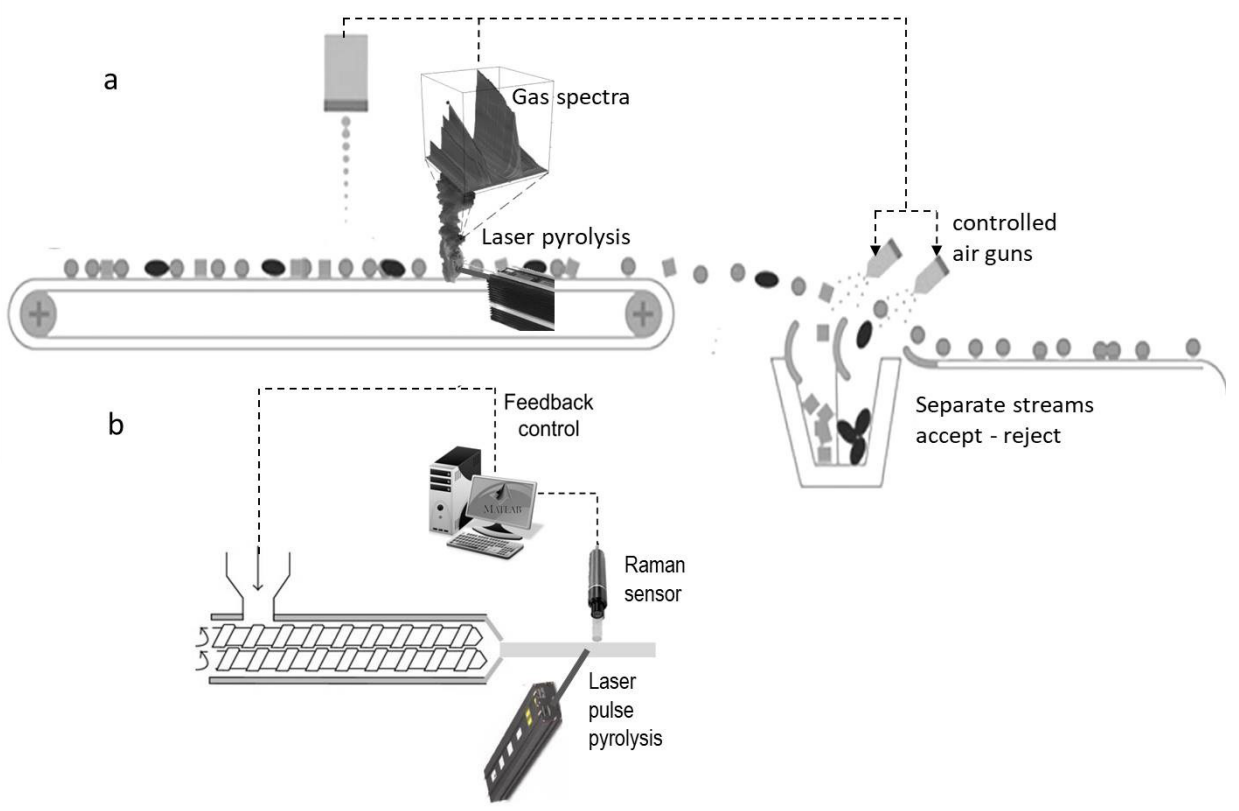

Fig. 2 Use of LP-FTIR for chemical identification of black pieces at waste sorting technology (a), control of intumescent flame retardant content through feedback from laser pyrolysis assisted Raman spectrometry (b)
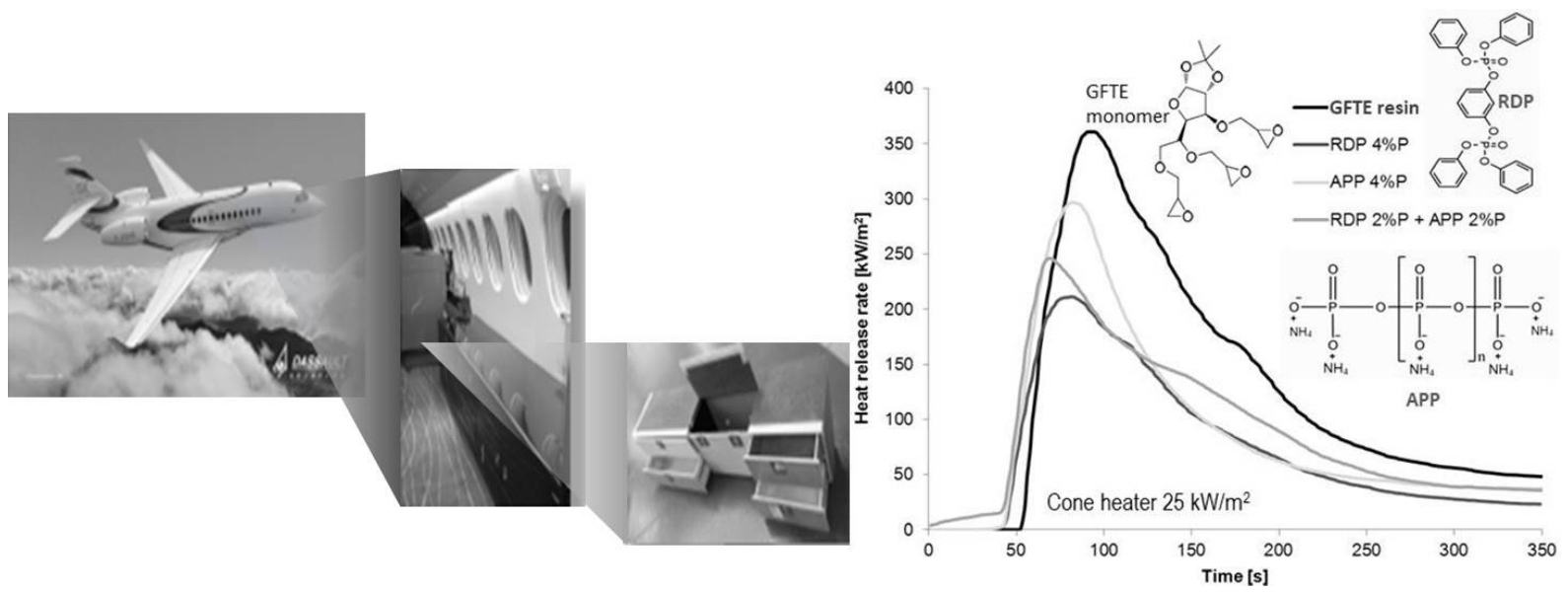

Fig. 3 Airplane-furniture made of bioepoxy composite and its heat release rate results

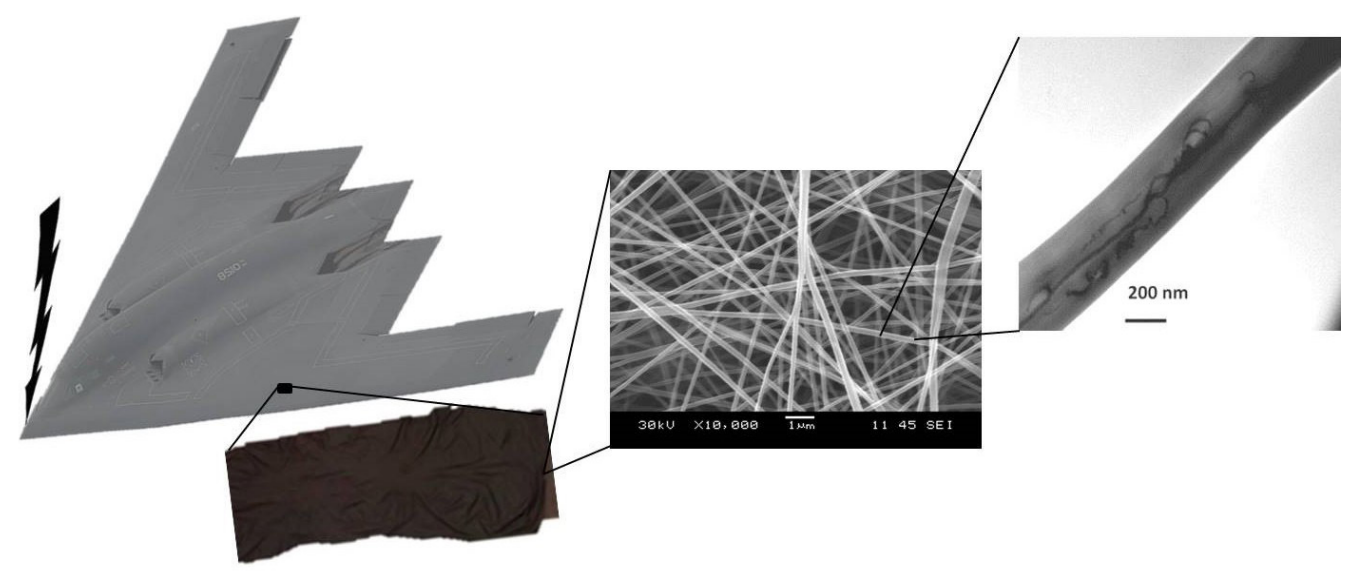

Fig. 4 Lightning protection of composite airplane using conductive nanofibrous epoxy layer 

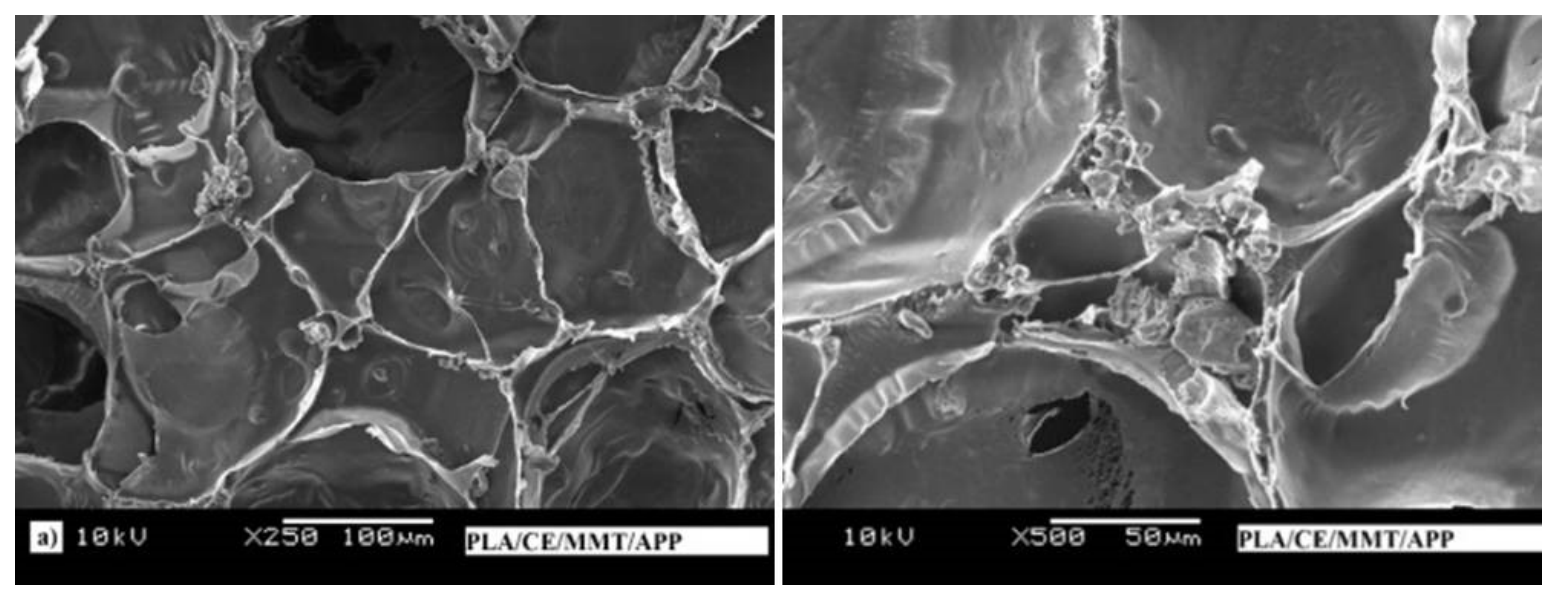

Fig. 5 SEM images of flame retarded PLA foams for light-weight fire-safe structures

the low consumption of energy and resistance against short circuit are of great importance. For this purpose biofoams have been developed in flame retarded form. Electron microscopic analyses revealed the flame retardant additives concentrated at the cell wall joints, as shown in Fig. 5, which proved to be of key importance regarding expandability and charring ability.

The biodegradable foams, when applied as cushion materials for packaging, have a significant environmental importance as well. In order to ensure the best foam structure for each application continuous non-destructive control of density is under development.

Green chemistry can advantageously use similar materials of high surface area for catalytic purposes. Utilizing the acquired skill in forming such materials, nanofibres have been prepared and used for organic and biocatalysis. The organo- and biocatalysts, prepared through bulk and surface modification of nanofibres (with active molecules and enzymes), preserved their activity even after several times of use [38, 39]. Other type of surface modification, achieved by plasma treatment, optimized the performance of electrospun biofibres made of various macromolecules, such as polycaprolactone and polyhydroxybutyrate, for using as scaffold in tissue engineering [40]. Online quantitative monitoring of the growth of cells can be performed using diffuse fibre-optic Raman spectroscopy [41].

\subsection{Technologies of innovative pharmaceuticals}

Raman micro-spectrometry combined with chemometry provides important support to the field of pharmaceutical technology. Qualitative, quantitative and structural analysis of pharmaceuticals, performed by Raman microscope, allows reverse engineering of solid dosage forms and identification of counterfeit products. Failures in

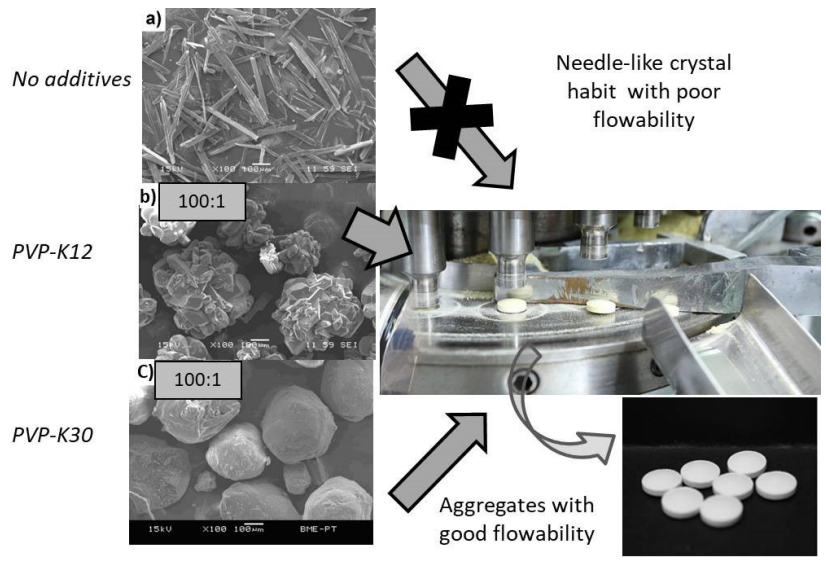

Fig. 6 Needle-like carvedilol crystals and spherical aggregates optimal for direct compression.

published compositions and their correction can be realized this way as it was performed in the case of isoptine [42]. Dual control, using fibre-optic Raman spectrometry combined with UV detection allowed us to add new abilities to reactors, in which drug syntheses or crystallization is performed. Polymer-assisted crystallization made possible, for example, to convert the hard-to-tablet needle-like carvedilol crystals to spheres suitable for direct compression as shown in Fig. 6. Interfacial polymer layer around the crystal particles made it feasible at very low $(<1 \%)$ polyvinylpyrrolidone concentration.

After applying similar control algorithms for bioprocesses [43] a particularly challenging new task occurred, requiring the elaboration of the first Raman-based monitoring, for fermentation of monoclonal antibodies (mAbs). Comparing the performance of Raman and NIR in-line spectroscopic analyses in the upstream process of this biodrug, clear advantage for the former one appeared in the detection of glucose concentration (which is essential for 
optimizing the fermentation circumstances). Encouraged by the achieved results [44] elaboration of continuous mAb-fermentation, assisted by Raman-based control, has been started.

Continuous (bio)pharmaceutical technology became the main subject of our research work in this field. Melt and wet extrusion of a several model drugs [45, 46] helped to develop a unique infrastructure suitable for forming drug-containing fine foamed structures. Supercritical pharmaceutical extrusion technology [47] proved to be feasible both for forming floating tablet of sustained release and fast-release milled foams, containing tolperisone and spironolactone respectively, according to Figs. 7 and 8 . Gear pump became an essential element of the controlled foaming technology, since a twin-screw extruder is not a pressure-generating device.

Nano-fibrous form of amorphous solid drug dispersions, prepared by various electrospinning (ES) techniques of increased productivity, using melt (MES) high speed (HSES), alternating current (ACES) circumstances, facilitate the bioavailability of drugs having poor water solubility [48-51]. Completely homogeneous distribution of drugs in polymer matrix was achieved this way according to Raman chemical mapping [52]. Ultrafast drug release of cardiovascular drug (carvedilol) was achieved from the prepared fibrous formulations (inserted into straws) suggesting that such a drug delivery system is suitable for storing the formulation in a stable solid dosage form and turning it rapidly into liquid form before administration [53]. The next steps towards realization of realtime release (i.e. evaluating and ensuring quality based on process data) in pharmaceutical technology were the development of controlled downstream processing (e.g. drying, milling) [54, 55]. These results, combined with flow drug chemistry, contribute towards the development of end to end pharmaceutical technology [56] with fully integrated interactive process units, the model of which is shown in Fig. 9.
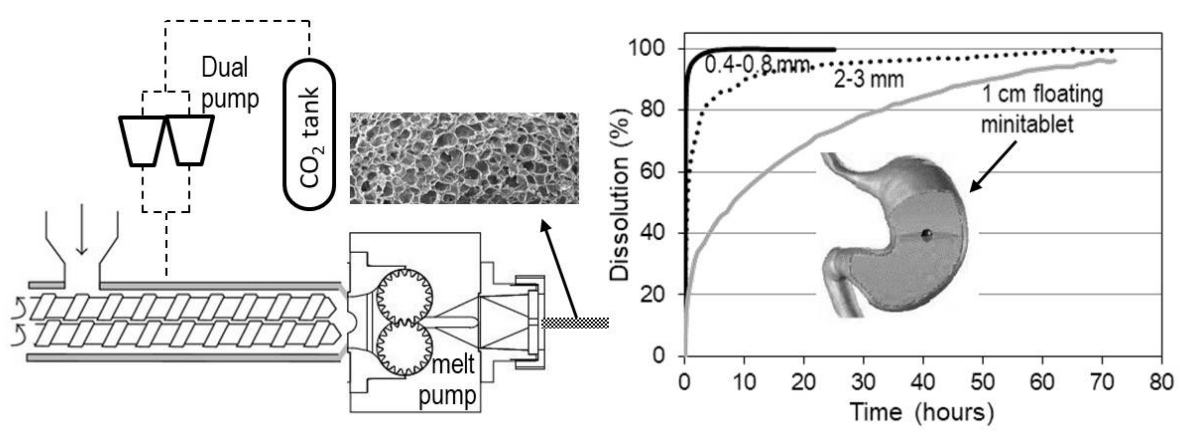

Fig. 7 Supercritical $(\mathrm{Sc})$ extrusion for forming foamed floating minitablet of tolperisone and release profiles depending on the (grinding rate) particle size (polymer system: polyvinyl acetate+polyvinylpyrrolidone+polyethyleneglycol)
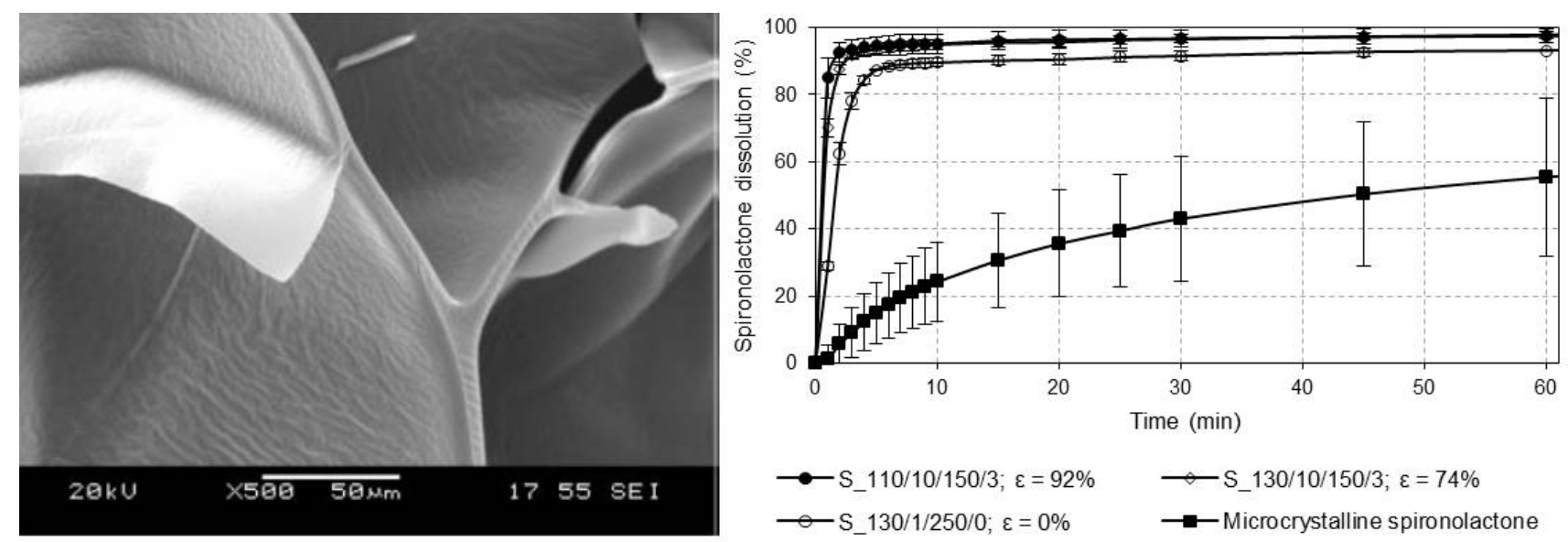

Fig. 8 Rapid release of spironolactone from well grinded foam (polymer: Eudragit E), Sample names were composed from extrusion parameters in the order of prefix, temperature $\left({ }^{\circ} \mathrm{C}\right)$, melt throughput $(\mathrm{g} / \mathrm{min})$, die pressure (bar), and $\mathrm{CO}_{2}(\%)$, separated by slashes. Porosity $(\%)$ is indicated by $\varepsilon$. 


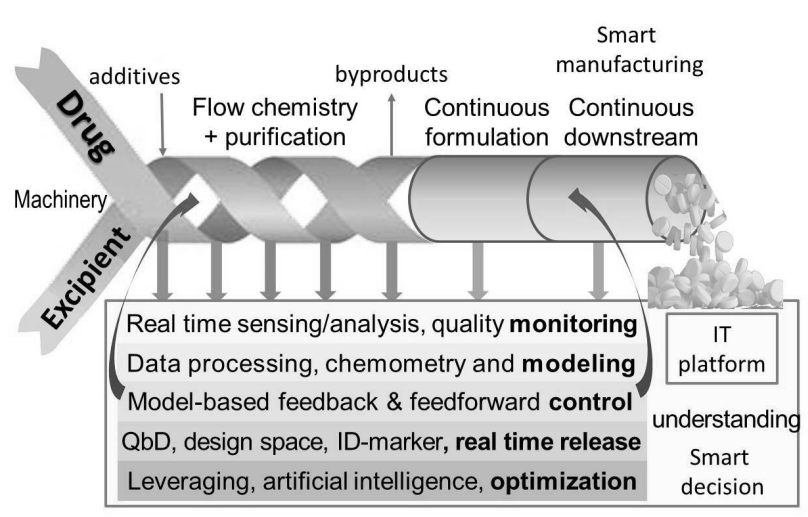

Fig. 9 Model of an integrated end to end pharmaceutical process assisted with information technology (IT) including real-time monitoring and control, quality by design (QbD), predictions and optimizations based on artificial intelligence

\section{Conclusion}

Environmentally motivated material and technology developments, shown through selected examples, can reinforce each other even if belonging to different domains of the industry. The presented ongoing research areas of the FirePharma group may express the commitment to innovative, controlled technologies, providing reliable production of various products. The real-time monitoring of the key

\section{References}

[1] Bertalan, G., Rusznák, I., Anna, P., Marosi, G., Nagy, T. T., Kelen, T. "Kinetik der hydrolytischen Lactampolymerisation auf Grundlage der neuesten Mechanismusvorstellungen", Acta Polymerica, 34(11-12), pp. 739-746, 1983.

https://doi.org/10.1002/actp.1983.010341115

[2] Marosi, G., Anna, P., Csontos, I., Márton, A., Bertalan, G. "New reactive additives for interface modification in multicomponent polyolefin systems", Macromolecular Symposia, 176, pp. 189-198, 2001.

https://doi.org/10.1002/1521-3900(200112)176:1<189::AIDMASY189>3.0.CO;2-Z

[3] Marosi, G., Bertalan, G., Rusznák, I., Anna, P. "Role of interfacial layers in the properties of particle-filled polyolefin systems", Colloids and Surfaces, 23(3), pp. 185-198, 1989.

https://doi.org/10.1016/0166-6622(89)80334-8

[4] Bánhegyi, G., Marosi, G., Bertalan, G., Karasz, F. E. "Studies of thermally stimulated current in polypropylene/calcium carbonate/surfactant systems", Colloid and Polymer Science, 270(2), pp. 113-127, 1992.

https://doi.org/10.1007/BF00652177

[5] Marosi, G., Márton, A., Csontos, I., Matkó, S., Szép, A., Anna, P., Bertalan, G., Kiss, É. "Reactive surfactants - new type of additive for multicomponent polymer systems", In: Zrínyi, M., Hórvölgyi, Z. (eds.) From Colloids to Nanotechnology. Progress in Colloid and Polymer Science, Vol. 125, Springer, Berlin, Heidelberg, Springer, 2004, pp. 189-193.

https://doi.org/10.1007/978-3-540-45119-8_32 material characteristics and the relevant control of process units, which are communicating with each other, extend a multi-level supervision to the whole technology (similarly to the bioregulation of human beings). This complex activity serves, after all, the aims of industry/pharma 4.0, which result in improved quality, safety and decrease of ecological footprint. Common features in the development of "industry of the future" can be presented at the university education through the realized material and technology innovations, the examples of which are shown here.

\section{Acknowledgement}

This research was financially supported by the Hungarian Scientific Research Fund (OTKA K112644, OTKA K120592, PD121171, PD121143). This work was supported by the National Research, Development and Innovation Fund in the frame of FIEK_16-1-2016-0007, NVKP_161-2016-0012 and GINOP-2.2.1-15-2016-00015 projects. K. Bocz, A Balogh, H. Pataki and A. Toldy are thankful for the János Bolyai Research Scholarship of the Hungarian Academy of Sciences. B. Szolnoki acknowledges the support received through the PREMIUM post-doctorate research program of the Hungarian Academy of Sciences.

[6] Marosi, G., Vaczulin, Z., Papp, I., Sallay, P., Csontos, I. "Diazotálás és kapcsolás számítógépes folyamatirányítása" (Computer process control of diazotization and coupling), Magyar Kémikusok Lapja, 51(5), pp. 218-219, 1996. (in Hungarian)

[7] Csontos, I., Marosi, G., Ravadits, I. "Construction and use of computer controlled laboratory batch reactor", Periodica Polytechnica Chemical Engineering, 42(2), pp. 115-123, 1998.

[8] Csontos, I., Marosi, G., Faigl, F., Ravadits, I., Kőmíves, J. "Development of organic chemical technologies using computer controlled model-reactor", Computers \& Chemical Engineering, 23(Supplement 1), pp. S995-S998, 1999.

https://doi.org/10.1016/S0098-1354(99)80235-X

[9] Csontos, I., Keszei, S., Marosfői, B., Szép, A., Anna, P., Marosi, G. "Direct synthesis of polymer emulsion/montmorillonite nanostructures for controlled drug release", European Journal of Pharmaceutical Sciences, 25(1), pp. S75-S77, 2005. https://doi.org/10.1016/j.ejps.2005.04.007

[10] Pataki, H., Csontos, I., Nagy, Z. K., Vajna, B., Molnar, M., Katona, L., Marosi, G. "Implementation of Raman Signal Feedback to Perform Controlled Crystallization of Carvedilol", Organic Process Research \& Development, 17(3), pp. 493-499, 2013. https://doi.org/10.1021/op300062t

[11] Csontos, I., Pataki, H., Farkas, A., Bata, H., Vajna, B., Nagy, Z. K., Keglevich, G., Marosi, G. J. "Feedback Control of Oximation Reaction by Inline Raman Spectroscopy", Organic Process Research \& Development, 19(1), pp. 189-195, 2015. https://doi.org/10.1021/op500015d 
[12] Marosi, G., Csontos, I., Ravadits, I., Tohl, A., Anna, P., Sommer, F., Botreau, M., Tran, M. D. "Thermal and Surface Analytical Study of Flame Retarded Polyolefins I. Interaction of Additives and Structure Formation", Journal of Thermal Analysis and Calorimetry, 56(3), pp. 1071-1080, 1999. https://doi.org/10.1023/A:1010188524681

[13] Marosi, G., Anna, P., Márton, A., Bertalan, G., Bóta, A., Tóth, A., Mohai, M., Rácz, I. "Flame-retarded polyolefin systems of controlled interphase", Polymers for Advanced Technologies, 13(1012), pp. 1103-1111, 2002 https://doi.org/10.1002/pat.284

[14] Marosi, G., Márton, A., Szép, A., Csontos, I., Keszei, S., Zimonyi, E., Toth, A., Almeras, X., Le Bras, M. "Fire retardancy effect of migration in polypropylene nanocomposites induced by modified interlayer", Polymer Degradation and Stability, 82(2), pp. 379-385, 2003. https://doi.org/10.1016/S0141-3910(03)00223-4

[15] Marosföi, B. B., Marosi, G. J., Szép, A., Anna, P., Keszei, S., Nagy, B. J., Martvonova, H., Sajó, I. E. "Complex activity of clay and CNT particles in flame retarded EVA copolymer", Polymers for Advanced Technologies, 17(4), pp. 255-262, 2006. https://doi.org/10.1002/pat.691

[16] Eisentraeger, F., Krause, W., Hoerold, S., Wanzke, W., Anna, P., Bertalan, G., Marosi, G., Marton, A., Zimonyi, E. "Flame protection additive for polymeric compositions having improved hydrothermal stability", US Patent App. 10/839,991, 2005.

[17] Farkas, E., Meszena, Z. G., Toldy, A., Matkó, S., Marosfői, B. B., Marosi, G. "Modelling of transport processes in a developing char", Polymer Degradation and Stability, 93(6), pp. 1205-1213, 2008. https://doi.org/10.1016/j.polymdegradstab.2008.02.010

[18] Anna, P., Bertalan, G., Marosi, G., Szep, A., Banhegyi, G. "Recyclable crosslinked polymers with saturated main chain and thermally reversible urethane crosslink points", US Patent App. 10/532,206, 2006.

[19] Matkó, S., Keszei, S., Csontos, I., Anna, P., Marosi, G., Zsuga, M., Borda, J., Nagy, G. "Fire Retarded Insulating Sheets from Recycled Materials", Macromolecular Symposia, 233(1), pp. 217-224, 2006. https://doi.org/10.1002/masy.200690021

[20] Matkó, S., Répási, I., Szabó, A., Bodzay, B., Anna, P., Marosi, G. "Fire retardancy and environmental assessment of rubbery blends of recycled polymers", Express Polymer Letters, 2(2), pp. 126-132, 2008. https://doi.org/10.3144/expresspolymlett.2008.17

[21] Almeras, X., Le Bras, M., Hornsby, P., Bourbigot, S., Marosi, G., Anna, P., Delobel, R. "Artificial Weathering and Recycling Effect on Intumescent Polypropylenebased Blends", Journal of Fire Sciences, 22(2), pp. 143-161, 2004. https://doi.org/10.1177/0734904104039609

[22] Marosi, G., Tohl, A., Bertalan, G., Anna, P., Maatoug, M. A., Ravadits, I., Bertóti, I., Toth, A. "Modified interfaces in multicomponent polypropylene fibers", Composites Part A: Applied Science and Manufacturing, 29(9-10), pp. 1305-1311, 1998. https://doi.org/10.1016/S1359-835X(98)00047-5

[23] Marosi, G., Bertalan, G., Anna, P., Tohl, A., Maatoug, M. A., Ravadits, I., Csontos, I. "Flame retarded, reinforced polypropylene technical fibres", Periodica Polytechnica Chemical Engineering, 42(2), pp. 125-130, 1998
[24] Torma, C. Z., Cséfalvay, E. "Nanofiltration: a final step in industrial process water treatment", Periodica Polytechnica Chemical Engineering, 62(1), pp. 68-75, 2018. https://doi.org/10.3311/PPch.10640

[25] Szép, A., Marosi, G., Marosföi, B., Anna, P., MohammedZiegler, I., Virágh, M. "Quantitative analysis of mixtures of drug delivery system components by Raman microscopy", Polymers for Advanced Technologies, 14(11-12), pp. 784-789, 2003. https://doi.org/10.1002/pat.395

[26] Szép, A., Szabó, A., Marosi, G., Bálint, M., Bódis, A., Csernák, L. "Micro-Raman spectroscopy for quantitative chemical mapping", European Journal of Pharmaceutical Sciences, 25(1), pp. S194S196, 2005. https://doi.org/10.1016/j.ejps.2005.04.007

[27] Marosi, G., Anna, P., Nagy, S., Matkó, S., Antal, I. "New concepts in formulation form extrusion to quantitative micro-spectroscopy", European Journal of Pharmaceutical Sciences, 25(1), pp. S27-S29, 2005. https://doi.org/10.1016/j.ejps.2005.04.007

[28] Csontos, I., Rónaszegi, K., Szabó, A., Keszei, S., Anna, P., Fekete, P., Marosi, G., Nagy, T. "Controlled technology for forming a nanostructured polymer coating for solid pharmaceuticals", Polymers for Advanced Technologies, 17(11-12), pp. 884-888, 2006. https://doi.org/10.1002/pat.773

[29] Bocz, K., Bárány, T., Toldy, A., Bodzay, B., Csontos, I., Madi, K., Marosi, G. "Self-extinguishing polypropylene with a mass fraction of $9 \%$ intumescent additive - A new physical way for enhancing the fire retardant efficiency", Polymer Degradation and Stability, 98(1), pp. 79-86, 2013. https://doi.org/10.1016/j.polymdegradstab.2012.10.029

[30] Bocz, K., Igricz, T., Domonkos, M., Bárány, T., Marosi, G. "Selfextinguishing polypropylene with a mass fraction of $9 \%$ intumescent additive II - Influence of highly oriented fibres", Polymer Degradation and Stability, 98(12), pp. 2445-2451, 2013. https://doi.org/10.1016/j.polymdegradstab.2013.06.011

[31] Bocz, K., Decsov, K. E., Farkas, A., Vadas, D., Bárány, T., Wacha, A., Bóta, A., Marosi, G. "Non-destructive characterisation of all-polypropylene composites using small angle X-ray scattering and polarized Raman spectroscopy", Composites Part A: Applied Science and Manufacturing, 114, pp. 250-257, 2018. https://doi.org/10.1016/j.compositesa.2018.08.020

[32] Marosfői, B. B., Marosi, G., Szabó, A., Vajna, B., Szép, A. "Laser pyrolysis micro-spectroscopy for modelling fire-induced degradation of ethylene-vinyl acetate systems", Polymer Degradation and Stability, 92(12), pp. 2231-2238, 2007. https://doi.org/10.1016/j.polymdegradstab.2007.02.026

[33] Bodzay, B., Fejös, M., Bocz, K., Toldy, A., Ronkay, F., Marosi, G. "Upgrading of recycled polypropylene by preparing flame retarded layered composite", Express Polymer Letters, 6(11), pp. 895-902, 2012. https://doi.org/10.3144/expresspolymlett.2012.95

[34] Toldy, A., Niedermann, P., Rapi, Zs., Szolnoki, B. "Flame retardancy of glucofuranoside based bioepoxy and carbon fibre reinforced composites made thereof", Polymer Degradation and Stability, 142, pp. 62-68, 2017 https://doi.org/10.1016/j.polymdegradstab.2017.05.024 
[35] Molnár, K., Szebényi, G., Szolnoki, B., Marosi, G., Vas, L. M., Toldy, A. "Enhanced conductivity composites for aircraft applications: carbon nanotube inclusion both in epoxy matrix and in carbonized electrospun nanofibers", Polymers for Advanced Technologies, 25(9), pp. 981-988, 2014. https://doi.org/10.1002/pat.3339

[36] Matkó, S., Toldy, A., Keszei, S., Anna, P., Bertalan, G., Marosi, G. "Flame retardancy of biodegradable polymers and biocomposites", Polymer Degradation and Stability, 88(1), pp. 138-145, 2005. https://doi.org/10.1016/j.polymdegradstab.2004.02.023

[37] Bocz, K., Szolnoki, B., Marosi, A., Tábi, T., Wladyka-Przybylak, M., Marosi, G. "Flax fibre reinforced PLA/TPS biocomposites flame retarded with multifunctional additive system", Polymer Degradation and Stability, 106, pp. 63-73, 2014. https://doi.org/10.1016/j.polymdegradstab.2013.10.025

[38] Sóti, P. L., Telkes, L., Rapi, Z., Tóth, A., Vigh, T., Nagy, Z. K., Bakó, P., Marosi, G. "Synthesis of an Aza Chiral Crown Ether Grafted to Nanofibrous Silica Support and Application in Asymmetric Michael Addition", Journal of Inorganic and Organometallic Polymers and Materials, 24(4), pp. 713-721, 2014. https://doi.org/10.1007/s10904-014-0037-9

[39] Sóti, P. L., Weiser, D., Vigh, T., Nagy, Z. K., Poppe, L., Marosi, G. "Electrospun polylactic acid and polyvinyl alcohol fibers as efficient and stable nanomaterials for immobilization of lipases", Bioprocess and Biosystems Engineering, 39(3), pp. 449-459, 2016. https://doi.org/10.1007/s00449-015-1528-y

[40] Hirsch, E., Nacsa, M., Ender, F., Mohai, M., Nagy, Z. K., Marosi, G. "Preparation and Characterization of Biocompatible Electrospun Nanofiber Scaffolds", Periodica Polytechnica Chemical Engineering, 2018.

https://doi.org/10.3311/PPch.12854

[41] Bergholt, M. S., Albro, M. B., Stevens, M. M. "Online quantitative monitoring of live cell engineered cartilage growth using diffuse fiber-optic Raman spectroscopy", Biomaterials, 140, pp. 128-137, 2017. https://doi.org/10.1016/j.biomaterials.2017.06.015

[42] Vajna, B., Pataki, H., Nagy, Z., Farkas, I., Marosi, G. "Characterization of melt extruded and conventional Isoptin formulations using Raman chemical imaging and chemometrics", International Journal of Pharmaceutics, 419(1-2), pp. 107-113, 2011. https://doi.org/10.1016/j.ijpharm.2011.07.023

[43] Hirsch, E., Pataki, H., Farkas, A., Bata, H., Vass, P., Fehér, C., Barta, Z., Párta, L., Csontos, I., Ballagi, A., Nagy, Z. K., Marosi, G. J. "Raman-Based Feedback Control of the Enzymatic Hydrolysis of Lactose", Organic Process Research \& Development, 20(10), pp. 1721-1727, 2016.

https://doi.org/10.1021/acs.oprd.6b00212

[44] Kozma, B., Hirsch, E., Gergely, S., Párta, L., Pataki, H., Salgó, A. "On-line prediction of the glucose concentration of $\mathrm{CHO}$ cell cultivations by NIR and Raman spectroscopy: Comparative scalability test with a shake flask model system", Journal of Pharmaceutical and Biomedical Analysis, 145, pp. 346-355, 2017.

https://doi.org/10.1016/j.jpba.2017.06.070
[45] Nagy, Z. K., Balogh, A., Vajna, B., Farkas, A., Patyi, G., Kramarics, Á., Marosi, G. "Comparison of Electrospun and Extruded Soluplus ${ }^{\circledR}$-Based Solid Dosage Forms of Improved Dissolution", Journal of Pharmaceutical Sciences, 101(1), pp. 322-332, 2012. https://doi.org/10.1002/jps.22731

[46] Madarász, L., Nagy, Z. K., Hoffer, I., Szabó, B., Csontos, I., Pataki, H., Démuth, B., Szabó, B., Csorba, K., Marosi, G. "Realtime feedback control of twin-screw wet granulation based on image analysis", International Journal of Pharmaceutics, 547(1-2), pp. 360-367, 2018.

https://doi.org/10.1016/j.ijpharm.2018.06.003

[47] Vigh, T., Sauceau, M., Fages, J., Rodier, E., Wagner, I., Sóti, P. L., Marosi, G., Nagy, Z. K. "Effect of supercritical $\mathrm{CO}_{2}$ plasticization on the degradation and residual crystallinity of melt-extruded spironolactone", Polymers for Advanced Technologies, 25(10), pp. 1135-1144, 2014.

https://doi.org/10.1002/pat.3367

[48] Nagy, Z. K., Nyúl, K., Wagner, I., Molnár, K., Marosi, G. "Electrospun water soluble polymer mat for ultrafast release of Donepezil HCl", Express Polymer Letters, 4(12), pp. 763-772, 2010. https://doi.org/10.3144/expresspolymlett.2010.92

[49] Nagy, Z. K., Balogh, A., Drávavölgyi, G., Ferguson, J., Pataki, H., Vajna, B., Marosi, G. "Solvent-Free Melt Electrospinning for Preparation of Fast Dissolving Drug Delivery System and Comparison with Solvent-Based Electrospun and Melt Extruded Systems", Journal of Pharmaceutical Sciences, 102(2), pp. 508517, 2013.

https://doi.org/10.1002/jps.23374

[50] Nagy, Z. K., Balogh, A., Démuth, B., Pataki, H., Vigh, T., Szabó, B., Molnár, K., Schmidt, B. T., Horák, P., Marosi, G., Verreck, G., Van Assche, I., Brewster, M. E. "High speed electrospinning for scaled-up production of amorphous solid dispersion of itraconazole", International Journal of Pharmaceutics, 480(1-2), pp. 137-142, 2015.

https://doi.org/10.1016/j.ijpharm.2015.01.025

[51] Balogh, A., Cselkó, R., Démuth, B., Verreck, G., Mensch, J., Marosi, G., Nagy, Z. K. "Alternating current electrospinning for preparation of fibrous drug delivery systems", International Journal of Pharmaceutics, 495(1), pp. 75-80, 2015. https://doi.org/10.1016/j.ijpharm.2015.08.069

[52] Farkas, A., Nagy, B., Marosi, G. " Quantitative Evaluation of Drug Distribution in Tablets of Various Structures via Raman Mapping", Periodica Polytechnica Chemical Engineering, 62(1), pp. 1-7, 2018. https://doi.org/10.3311/PPch.10143

[53] Farkas, B., Balogh, A., Farkas, A., Domokos, A., Borbás, E., Marosi, G., Nagy, Z. K. "Medicated Straws Based on Electrospun Solid Dispersions", Periodica Polytechnica Chemical Engineering, 62(3), pp. 310-316, 2018.

https://doi.org/10.3311/PPch.11931

[54] Szabó, E., Démuth, B., Nagy, B., Molnár, K., Farkas, A., Szabó, B., Balogh, A., Hirsch, E., Nagy, B., Marosi, G., Nagy, Z. K. "Scaled-up preparation of drug-loaded electrospun polymer fibres and investigation of their continuous processing to tablet form", Express Polymer Letters, 12(5), pp. 436-451, 2018. https://doi.org/10.3144/expresspolymlett.2018.37 
[55] Nagy, B., Farkas, A., Gyürkés, M., Komaromy-Hiller, S., Démuth, B., Szabó, B., Nusser, D., Borbás, E., Marosi, G., Nagy, Z. K. "In-line Raman spectroscopic monitoring and feedback control of a continuous twin-screw pharmaceutical powder blending and tableting process", International Journal of Pharmaceutics, 530(12), pp. 21-29, 2017.

https://doi.org/10.1016/j.ijpharm.2017.07.041
[56] Balogh, A., Domokos, A., Farkas, B., Farkas, A., Rapi, Z., Kiss, D., Nyiri, Z., Eke, Z., Szarka, G., Örkényi, R., Mátravölgyi, B., Faigl, F., Marosi, G., Nagy, Z. K. "Continuous end-to-end production of solid drug dosage forms: Coupling flow synthesis and formulation by electrospinning", Chemical Engineering Journal, 350, pp. 290 299,2018

https://doi.org/10.1016/j.cej.2018.05.188 